\title{
CONTESTATIONS OF VISIBILITY - A CRITIQUE OF DEMOCRATIC VIOLENCE
}

\author{
S. H. Kumalo \\ Department of Political Science \\ University of Pretoria \\ Pretoria, South Africa \\ e-mail: s.kumalo@icloud.com / https://orcid.org/0000-0002-6591-5995
}

\section{ABSTRACT}

Analysing the contestation that was inaugurated by the \#RhodesMustFall movement, I think through the ways in which it - this contestation - signalled an attempt at reclaiming Black ontology in the Historically White University (HWU). Tracing the uses of what has been defined as democratic violence, I showcase how this response is misplaced owing to the neglect that has characterised the Black Archive in the University. In simple terms, my argument makes a case for the uses of alternative responses as opposed to democratic violence. This is rooted in a desire to see Black ontology treated with the deference deserving of this category of being, in a space that has been historically defined by the denigration of Blackness, i.e. the HWU.

I begin by defining democratic violence for the purposes of setting-up my critique of this response. In the second move, I showcase how an alternative can be sourced from the Black Archive, which has been neglected. I conclude the article by highlighting how a Fanonian conception of violence is misplaced in our context.

Keywords: language, pedagogy, ethics, academic freedom, ontological legitimacy

\section{INTRODUCTION}

The rupture witnessed in institutions of higher learning, specifically in Historically White Universities (HWUs) through Chumani Maxwele's flinging human excrement at the statue of Cecil John Rhodes - at the University of Cape Town in 2015 - indicated a shift in the academic landscape of South Africa. Through this act which I interpret as an attempt at reclaiming Black ontology in historically white spaces; HWUs were reduced from their status as citadels that cannot be questioned for their institutional culture. Framing this act, of flinging human excrement at the statue of Rhodes, as an attempt at ontological reclamation is based on an identification of two factors that inform the call to decolonise the South African University. ${ }^{1}$ The first is an active resistance of perceived continued colonial impositions that obfuscate Black ontology, which facilitates the second move. The second move is an attempt to clearly articulate Black ontology, outside the delimitations prescribed by the colonial encounter, which obfuscates Black ontology - for Blackness - due to what has been termed epistemic 
impositions. Blackness in this schema is rendered unable to articulate Black ontology as a result of an authentic and pure conception of Black ontology that is premised on colonial predeterminations (Mandani 2005). ${ }^{2}$ I argue - for two reasons, one as detailed in endnote 2 that an authentic and pure conception of Black ontology is impossible owing to the entanglements of Blackness with coloniality. Treating the matter of entanglements becomes the secondary point that constitutes my claim of an inability to lay claim to an authentic conception of Blackness.

This is to say that one cannot deny the complexity that exists within the project of identity formation in a (post)-colonial context. ${ }^{3}$ This complexity that is characterised by Blackness attempting to subvert prescriptions derived from colonial impositions, while being unbale to break free from these impositions gives rise to the thought that Black ontology in the contemporary South African context is illusive. While the debate on higher education decolonisation appeals to this political designator - Black ontology - for emancipatory ends, defining Black ontology is illusive because of the colonial moment of encounter. Through ontological reframing that comes about as a result of colonialism; contemporary entanglements with coloniality problematise supplications to notions of cultural purity and authenticity which may be used as an emancipatory strategy of decolonising the University.

This complication is what gives rise to the analysis presented here, which considers the use of democratic violence as a response to the epistemic harms endured by Blackness in HWUs. My objective lies in critiquing the use of democratic violence on the basis that there are no clear definitions of Black ontology in the contemporary South African University. I conduct this critique by firstly defining democratic violence and its uses, which leads me to a consideration of what constitutes Black ontology. This consideration will reflect on Black ontology and its entanglements with coloniality, subsequently substantiating the critique of the use of democratic violence through a detailed analysis that exposes how Blackness has itself neglected the Black Archive, which should be used instead of democratic violence in challenging Eurocentric paradigms of thought. I conclude by considering how the Fanonian conception of violence is misused, in our context, in order to showcase how the \#Fallist movements did not meet the conditions of the suspension of the ethical, which necessitates the use of violence as an emancipatory tool.

\section{DEFINING DEMOCRATIC VIOLENCE}

Democratic violence, as it is used here, is best defined by Ramose $(2016,4)$ when he frames it as a manifestation of violence that "consists only in the coercion of persuasion" - an interpretation that comes from Honderich (1980). Ramose (2016) further goes on to define 
democratic violence as an "ethical demand for the equality of condition, that is, substantive as opposed to formal equality". Democratic violence in this sense becomes the catalyst for securing justice: epistemic, social, and economic justice in a context like South Africa that continues to be plagued by structural inequalities and modes of oppression maintained through - what has been termed - epistemicides ${ }^{4}$ witnessed in the University. Epistemicide and its uses in contemporary calls for decolonisation will be taken up in my argument through a consideration of the constituent elements of Black ontology, which like any other identity is defined by continuously negotiated conceptions and articulations.

In my consideration of the constitutive elements of Black ontology, I reject the politically motivated assertions that frame Blackness as the constant victim, through revealing the complicities of Blackness in contemporary coloniality. I should, however, state that I appreciate the decolonial propositions that have come from thinkers in the social sciences (Nyoka 2013; Morreira, and Hayakawa 2015) who have revealed the challenges that arrest the South African University through reproductions of colonialism and coloniality ${ }^{5}$ through academic dependency.

My contribution, then, to the debate on higher education decolonisation in South Africa is inspired by the following question: was the protest action witnessed in the contemporary University justified? Critiquing emancipatory politics predicated on democratic violence is motivated by my interpretation of the University as an institution dedicated to the contestation of knowledge and its production, while further substantiation comes from the claim, which I posit and defend, that Black ontology is not static and is characterised by contestations owing to the (post)-colonial condition that defines South Africa. ${ }^{6}$

The use of democratic violence as a response to what has been framed as ontological negations must heed a crucial caution that warns against essentialising certain positions while simultaneously silencing others. I argue here that the act of privileging any voice in the academe recreates the essentialisms that the decolonial project attempts to contest and problematise. Recreating essentialisms signifies the pitfalls of one mode of damaged life being replaced by another, a caution flagged by Mbembe (2015) as he thinks through the \#Fallist movement in its initial phase in the country.

In reviewing the state of South African political life, Mbembe cautions that one state of damaged life, should not be replaced by another (2015). My critique of democratic violence reveals how the \#Fallist movement progressively recreated essentialising discourses that silenced and dismissed dissenters.

Mbembe's (2015) caution is pertinent in a context where the \#FeesMustFall movement quickly turned violent as South Africans watched from a distance, the stand-off between 
students $^{7}$ and the police ${ }^{8}$ on university campuses ${ }^{9}$. This violence, that was used by students, can be interpreted as replacing one mode of damaged life with another as students sought to overturn a system perceived as inherently unjust. The students' claims of injustice were rooted in institutional responses to the instability that threatened to engulf the sector; these responses were perceived and portrayed as the ubiquitous surveilling, criminalisation and incarceration of Black students ${ }^{10}$. Through interpreting institutional responses as injustice two moves were made in the \#Fallist movement discourse; first - institutional responses were likened to apartheid systems of domination and control ${ }^{11}$. Secondly - this likening of the contemporary HWU to an institution operating with and through apartheid tactics birthed the prerequisite political move that necessitated the use of democratic violence. Democratic violence in this regard denotes uprooting this fundamental injustice and replacing it with a just institution that delivers on the promise of democracy and substantive freedom. As Ramose would have it, the act of students was an act predicated on an "ethical demand for equality of condition" (Ramosa 2016, 4).

In earnest, one can, at length - through decolonial articulations (see Grosfoguel 2013), argue for the legitimacy of the use of democratic violence in the contemporary academe as it was surveillance, criminalisation and incarceration that apparently drove students to the use of said violence. However, I posit that this mode of resistance - democratic violence - was devoid of the ethical principles that constitute the collegial environment that is the University. To frame the response that necessitated the use of democratic violence as being devoid of the ethical principles that govern the University is premised on my understanding of the University as a space that primarily fosters knowledge production along with the cultivation of the new generation of intellectuals. This conception of the University is predicated on a definition of the ethical duty of intellectuals to society. However, I am not concerned with the definitional delimitations of such duty, but rather a critique of democratic violence.

Subsequent to his remarks, Mbembe (2015) was critiqued by the student body, with hahHalloran ${ }^{12}$ arguing that Mbembe (2015) had conflated the Black Student Movement (BSM) with the actions of vandals. This conflation it is suggested by O'Halloran, elided an acknowledgment that the contemporary struggle sought to challenge white supremacy in the academe, a suggestion that likened the University to an apartheid institution. In this argument the contemporary Black Student Movement sought to defend the strategies used by the student body, as valid and necessary. Implicit in O'Halloran's defence was the notion that through challenging the academe using democratic violence, the student body was attempting a reclamation of the University and were redefining the institutional space into one that reflects Black ontology while giving it - Black ontology - a sense of belonging and deference. 
Acknowledging the desire of Black students to be seen as ontologically legitimate in whitely spaces, I trouble the ways in which such desire was expressed. Troubling the use of democratic violence comes as a result of a deep engagement with Fanon's The Wretched of the Earth ${ }^{13}$ (Fanon 1995/1967), a conversation to which I will return momentarily. For the following discussion, I turn to an analysis of a reflective appraisal of Black ontology using Fanon's $(1995 / 1967)$ work.

\section{DEFINING BLACK ONTOLOGY}

In the first instance, as detailed in cursory form in endnote 2 , the notion of authenticity denies Blackness the range that constitutes it - as identity. This is to say that in appealing to notions of authenticity the variance that constitutes Black identity and - as a derivative - Black ontology is denied and rendered problematic when it seeks to assert its place in the socio-political landscape. What this framework presents is an essentialised conception of identity that feeds into the idea of Blackness/Indigeneity as fixed; a conception that served colonial interests that were determined in viewing Africa and the African as "retarded, gradual, and backward" (Mudimbe 1988, 33). As Mamdani $(2005,6)$ suggests it, this mode of framing Black ontology along with its customs as static was derived from the desire of "colonial power [which] sought to construct native custom as unchanging and singular".

Owing to the illusory nature of Black ontology, as a result of the texture, nuance and variance that defines Blackness, I sceptically suggest that Black ontology is based on cultural practices, language and conceptions of personhood rooted in collective/communal relations. Communal relations secure a sense of belonging (Ikuenobe 2006), while questions regarding who we are (as members of said community), are inherently tied to where we are (Dixon, and Durrheim 2000). Through developing self-referential narratives of the University, Black ontology can begin to articulate its positionality outside the experience of being unhomed; an experience that is detailed by Bangani and Kapp (2007). In view of this, I wish to define Black ontology through revealing the complexity of its history, specifically in the South African context.

Blackness/Indigeneity in the context of South Africa has continuously been defined as deficient owing to systems of oppression and attempted erasures through systematic coloniality- apartheid legislation (Nkosi 1989). While the category of "Blackness" has, in the contemporary literature, become synonymous with Biko's (2004/1978) treatment of this category; a category that can be seen as having jettisoned "Indigeneity"; I make reference to it owing to Kumalo's (2021) argument when he writes about solidarity between decolonial struggles and efforts that are constitutive of the global movement of decolonisation in the 
academe presently. Kumalo $(2021,13)$ frames this submission thusly,

"[...] solidarity globally further drive the objective of highlighting the similarities that define decoloniality as a global undertaking. This is to say that we, in the South African context, realise that there are continuing struggles - each of which are modified by the context specificities of Canada, the United Kingdom, the United States and Germany; specificities that irrespectively require our collective efforts through modes of learning and teaching that are inclusive, i.e. decolonial and democratic."

This is to say that the use of Blackness/Indigeneity as deployed in this argument does not collapse the categories, however, highlights the importance of both - as useful designators of the "peoples of the margin", a concept that I borrow from Dussel's (1985) work.

Systematically attempted erasures are maintained through the devaluation of Black epistemic positions witnessed in the continued importation of theory from the north (Nyoka 2013) while there exists a Black Archive that continues to be undervalued and neglected even by Black intellectuals. Resultantly, Black ontology - through devaluation - is marginalised rendering Blackness to be viewed as second-class citizens in the University; a move that ensues from the structure of knowledge in the westernised university. Ramon Grosfoguel (2013) writes about the role of colonialism and coloniality in fashioning the contemporary structure of the University and argues that privileging epistemic frameworks developed in the west, results in the silencing of contemporary modes of being among the Indigenous peoples of the global South. This epistemic privilege, that is enjoyed by European ways of knowing, maintains structures of coloniality (Grosfoguel 2013, 77) in the knowledge production domain. It is from these complexities, that necessitate the recognition of variance and multiplicity within Black identity, along with the entanglements with colonial structures and the resistance against colonialism that I suggest that Black ontology is illusive. There is another reductive and constraining move, one that aims to define Black ontology as reactionary. This move is rooted in the continued resistance of Blackness to colonial imposition and frames Blackness as largely constituted by reactions and responses to incursion. As the reader will see in the exploration of the Black Archive, the material contained therein resists this notion - as argued by Kumalo (2020a). Yvette Abrahams (2003), writes about the disjunctures and dysfunctions caused by colonialism, resulting in the social, cultural, interpersonal and intrapersonal ruptures derived from coloniality.

It is of further significance to note how colonialism functioned to displace and disrupt established modes of existence in all territories that are toady defined as post-colonial ${ }^{14}$ societies. This displacement - can be understood as the interruption of "place-belonging" (Dixon, and Durheim 2000, 29) - refers to the denial of self-definition through the imposition 
of colonial modes of being. Denial may be framed contemporarily, in the University, as the failure of intellectuals to take seriously the contribution of Black/Indigenous thinkers in traditional disciplines such as Political Sciences, Sociology, History and Art Theory - to name a few. This aversion to knowledge developed by Black/Indigenous thinkers is premised on the thinking that privileges Eurocentric epistemic paradigms at the expense of local knowledge systems. Boughey and McKenna (2016) argue that these proclivities that privilege western epistemic paradigms generate the contestation of institutional and disciplinary knowledge systems, "which reinforce the knowledge of the powerful". To exist at the periphery, subsequently, necessitates modes of resistance that push back on epistemic and ontological erasures. As stated above then, the aim is to critique the use of democratic violence as a mode of resistance in the University. For this project I examine Fanon's The Damned of the Earth in order to fully detail how contemporary circumstances did not necessitate the suspension of the ethical. I maintain that it is only through the nexus of social conditions revealed by Fanon (1995/1952) that there can be the suspension of the ethical, which heralds the use of violence for emancipatory ends.

In using Fanon (1995/1952) to detail the social conditions that necessitate the suspension of the ethical, I must begin by stating that although Fanon has been critiqued for his work wherein he considered the use violence, he was a man, whom "despite his philosophical aversion to notions of human 'nature'... his moral [character was defined by his] detestation of violence" (Gordan 2015, 9).

In his discussion on the use of violence as an emancipatory tool in the decolonial struggle, Fanon notes that " $[\mathrm{t}]$ he native who decides to put the programme into practice, and to become its moving force, is ready for violence at all times" (Fanon 1995/1952, 29). With this framework in mind I object to the misuses of Fanonian thought in South Africa. My objection is predicated on a distinction that the \#Fallist movements, and their attendant discourses, failed to make when considering the peripheral position of Black ontology in the academe. While continued modes of silencing abound through epistemic imposition, the South African context differs from the Algerian situation in that the "zone of non-being" that Fanon describes in The Damned of the Earth has been resisted in our academe. Postcolonial and decolonial scholars, in our context, have resisted dehumanisation that renders Black ontology in the zone of non-being through reinscribing Black ontology by using Indigenous languages and developing knowledge in this medium. The fallacy of continued suppositions about the zone of non-being in our context arises from misappropriations of Africana philosophy that articulates the uprooting of Black ontologies from their various contexts through the Atlantic slave trade. Put crudely, such a claim, as the necessity of the use of violence, can only hold if it is substantiated by mis-readings 
that mistake our context for the African American experience - which contemporarily - is without language. This lack of an African lexicography is what might constitute the dearth of alternative ways out of a problem that exists owing the competing identities in a given sociopolitical locale. In possessing an African lexicon, I am of the view that this can be the tool by which domination, injustice, and oppression are resisted. While this scholarship, as developed by the Africana philosophy tradition is useful, I am of the view that it has been misappropriated to the South African context without a detailed analysis of the conditions of possibility that exist for Black ontology. Even as Black ontology has been reframed and appropriated for the uses of white supremacy and domination ${ }^{15}$, ours is not a condition that has fully been subjected to epistemicide (Kumalo 2020a).

This claim is premised on the reality that Black ontology and epistemology have not been absolutely annihilated. While I appreciate the objection that might be a bit more generous in reading the uses and application of the concept of epistemicide, a position that argues that the concept does not denote the successful and complete erasure of these knowledge systems, Kumalo's (2020a) analysis showcases the dangers that are inherent in propounding this claim.

To illustrate this point, I return to The Damned of the Earth, wherein Fanon describes the point at which the colonised realise their agency and use it as a mode of resisting the colonial condition. Fanon writes, “[f]or if in fact, my life is worth as much as the settler's, his glance no longer shrivels me up, nor freezes me, and his voice no longer turns me into stone. I am no longer on tenterhooks in his presence; in fact, I don't give a damn for him" (emphasis added) (Fanon 1995/1952, 35). It is this realisation, which I interpret as the agency of Black ontology, that has facilitated continued resistance against colonial violence through epistemic imposition. The agency of Black ontology in our context has resulted in resistance strategies that have sought to reinscribe Black ontology through the use of African languages (Nyembezi 1958; Mthembu 1985) in the academe, rendering whiteness as a bystander in the project of Black ontological articulations. I would suggest that the misappropriations of Africana philosophy in the South African context arise owing to the internalised white lies that have pushed the narrative that there is no knowledge, of epistemic worth, that has been develop by Blackness/Indigeneity; a claim that is rooted in the failure of whiteness to understand or learn Indigenous languages. Exhibiting an arrogance that is incomparable, whiteness in South Africa dismissed knowledge developed in African languages for the purposes of driving white lies that are the bedrock of the colonial project. As Fanon suggests and if the academe along with its practitioners are to sincerely heed his blueprint for decolonisation through appropriate readings of The Damned of the Earth, "[i]n the period of decolonisation, the colonised masses mock at these very values, insult them and vomit them up" (Fanon 1995/1952, 34). 
A response that would emulate what Fanon writes about vis-à-vis mocking the colonisers values lies in an earnest engagement with the Black Archive, and a willingness to bring these modes of being into the academe so as to begin articulating a sense of Black ontology that is augmented by the power structures of the knowledge making domain. This is not to say that what is sought after is a hegemonic idea of Blackness that is monolithic, as that would be a betrayal of the complexity that defines Blackness/Indigeneity as detailed above. What is sought rather, are ways of knowledge making that substantiate the agitations of the student body, who called for substantive revisions in what intellectuals teach and the practices to which they adhere in the University. With the demand that the University reflect the ontologies of the Black students post-1994, students challenged modes of silencing used against their experiential knowledge and testimonies. However, the act of challenging the academe has received relatively mild reception from Black intellectuals, through the continued neglect of the Black Archive, which is constitutive of the works of S. E. K. Mqhayi (1914), Tiyo Soga (1898), and Mazisi Kunene (1992) to mention a few. It is on the basis of this Black Archive, which is inscribed using both African and European languages ${ }^{16}$, that I make the claim of the misappropriation of Africana philosophy in our context.

Through institutional cultures - maintained through acts of marginalisation and a sense of neglect towards the Black Archive - that obfuscate the lived realities of Black ontologies, the academe bears witness to the continued epistemicide committed against Blackness, owing to the structure of knowledge in westernised universities (Grosfoguel 2013). Boughey (2002) argues that the Black student has been perceived as an "outsider in the academic discourse", owing to their lack of familiarity with academic literacy, which locates and frames the student as both disadvantaged and deficient, i.e. in need of capacitation. The narrative of the deficient student is contested by Angu, Boakye, and Eybers (2020) when they inquire whether we - as scholars - are suggesting that to be "literate" in the South African University denotes being able to produce knowledge in English. Literacy as framed in these terms needs to be understood within the definition given by Wicomb $(2018 / 1995,67)$ when she maintains, "[what] passes for the testing of literacy is none other than 'the social conventions of a dominant class, rather than universal logic." The deficiency discourse highlights a hegemonic knowledge production paradigm that devalues the epistemic positions of other knowledge forms. This lack of familiarity Boughey suggests elides "the innately racist labels of cognitive and cultural differences associated with apartheid" (Boughey 2002, 296) which can be challenged and subverted through the use of the Black Archive in curriculation strategies, as has been argued by Kumalo (2020b). This lack, that denotes the deficiency discourse, is exacerbated by the alienating curricula that is coded using a Eurocentric epistemic paradigm premised on 
modernity creating of the student what Boughey and McKenna (2016) term the decontextualised learner.

The inclusion of Blackness in the HWU can be viewed as an act of piecemeal tokenism, comparable to ontological negation. This inclusion has been seen through additive strategies that fail to substantively engage and intellectually appraise the Black Archive, substantiating claims of epistemicide and negation. To claim that inclusion has been slow and unwilling to listen to the voices of Blackness in the HWU begs the fundamental question at hand; is democratic violence the correct mode of engagement in an intellectual space? I am cautious and aware that in raising this question, I might evoke for some, the image of the citadel, which silences certain modes of existence within these institutions. Asking this question does not seek to reduce the struggle of the Black student to mere acts of vandalism and criminality. However, with the need for reflexivity, specifically in disciplines such as Philosophy - from which I write, these questions remain pertinent in the discussion of transformation and modes of democratising the University.

\section{Transforming the academe through the Black Archive}

Here, I conduct a comparative analysis between contemporary and historical forms of protest. In making reference to the historical (apartheid), I am not likening the contemporary academe to an institution that functions through the use of apartheid tactics of governance. In portraying the contemporary University as similar to the apartheid state, a move witnessed in the 2015 and 2016 \#Fallist movement narratives, \#Fallist activists illustrated a lack of imagination and an understanding of how this institution functions. A detailed analysis of the governing legislation, the vision and mission statements of universities along with lively community engagement projects suggest that the South African University is an institution committed to transforming society through teaching, learning and research. This dearth of imagination limits our conceptions of the University to - framing it rather as an institution that is characterised only by power relations and domination. While some scholars might be quick to claim that indeed this is what constitutes this institution, I am cautious of this move.

The claims of epistemicide must be reviewed in line with the reality that South Africa is no longer a repressive state that seeks to silence and eliminate any dissenting voice. In the University specifically, the idea of disagreement and challenging the norm/tradition has been embedded into the institutional cultures of the academe. I anticipate an objection to this claim - an objection that would frame my argument as a romanticisation of this institution. To this objection, my response is simple. I acknowledge that since the dawn of democracy, the sector has come to be defined by animosities that make up this contestation that is my focal point of 
analysis. Put differently, I am curious as to whether these differences can ever be used in the historical sense of creating a vibrant intellectual culture that supports the objective of advancing human development through the development of knowledge. In simpler form, I am interested in a vision of the University that is rooted in the contestation of ideas, opposing epistemic frameworks and challenging claims to truth through knowledge discovery; with these values used as the bedrock of the contemporary University.

This ambitious desire is, however, complicated by the real claims of silencing, repression and modes of ontological negation that exist in HWUs in the country. In view of this, I would like to suggest an alternative. The sector can work towards undoing the epistemic harms that have culminated in the claim of epistemicide on two accounts. First, if indeed South Africa is no longer marked by the seal of repression and the elimination of dissenting voices, then the academe ought to challenge Eurocentric epistemic paradigms by welcoming African epistemic positions inscribed through the Black Archive. The second move would be to harness the ideals that supposedly constitute the University as institution, this being the fact that the University is a space that is characterised by a contestation of knowledge claims, a contestation that is supported even in the work of Indigeneity scholars Nakata, Nakata, Keech and Bolt (2012). Nakata et al. (2012) argue that even Indigenous knowledge ought to be subjected to the same rigorous modes of testing and application that any knowledge system is subjected to in the University. This assessment of the validity of Indigenous knowledge should, however, be guided by intellectual collaboration between the institution and local knowledge workers, which strengthens one of the pillars that now governs the contemporary South African academe, this being the pillar of community engagement. By developing this schema, which brings Indigenous knowledge into the University through the Black Archive while also strengthening the intellectual collaboration between the University and the community, Black ontology selfdefines and begins to radically challenge Eurocentric epistemic positions.

This schema is, however, cautious not to fall into trappings of epistemic injustice (Maitra 2010), through the marginalisation of the voices that still exist at the margins. What is further useful in this schema is the centrality of and rigour with which the academe treats Black ontology and the Black Archive; a proposition that finds expression in Kumalo's (2020a) argument when he details the criticality that defines an engagement with the Black Archive. This resultantly eradicates the peripheral position of Blackness in the academe through enacting Fanon's claim that the colonised no longer regard whiteness with demigod status, “... in fact, I don't give a damn for him" (Fanon 1995/1952, 35). 


\section{APPRAISING FANONIAN VIOLENCE - AN ARGUMENT FOR THE ETHICAL}

In light of the dynamics that constitute the University, I suggest that the HWU understands the actions of the Black student as existing outside the tradition of the University. This is exemplified in the criminalisation of violent student protests through the harshest legitimate violence of the courts, police and internal disciplinary mechanisms. This conclusion - which defines violent student protest as existing outside of the University - is substantiated in how this social institution has been defined above, as a space that prides itself in the contestation of knowledge claims and the pursuit of knowledge through critical engagement and reflexivity. In some respects, however, violent student protest substantiates western epistemic paradigms, while framing the student in the deficiency discourse that depicts Blackness/Indigeneity as lacking the capacity to be a valid knower and knowledge producer. Gatekeeping epistemic access, in this way, demonstrates the tacit collusion of Blackness and whiteness in the claims of epistemicide, which have been problematised and challenged above in line with Kumalo's (2020a) critique. To reiterate the point, it is through an engagement with the Black Archive that Black ontology can begin to substantively decolonise the academe and open possibilities of epistemic access to the contemporary South African HWU.

In what follows I link epistemic access to epistemic justice through re-reading Concerning Violence as developed by Fanon. Fanon argues that "[ $\mathrm{t}]$ ruth is that which hurries on the breakup of the colonialist regime; it is that which promotes the emergence of the nation; it is all that protects the natives, and ruins the foreigners" (Fanon 1995/1952, 39). To make this move I frame epistemic justice, which facilitates epistemic access, as an engagement with the Black Archive that facilitates Blackness' rejection of the status of apprentice to the colonial descendent and their western epistemic paradigms. Such an engagement breaks-up the colonialist regime through ushering into the academe substantive engagements with the Black Archive. A substantive engagement with the Black Archive subverts the colonial conditions wherein "there is no truthful behaviour: and the good is quite simply that which is evil for 'them"' (Fanon 1995/1952, 39). In fracturing the colonial condition through the use of the Black Archive, Blackness is rendered the authorial voice of Black ontology, both in the written form as well as in the articulation of Black knowledge traditions. This framework moves away from a context wherein scholars such as Leonhard Praeg (2014) define themselves as the authority on subjects they cannot access owing an intellectual and epistemic arrogance that refuses to learn Indigenous languages while claiming authority on Indigenous thought. The selfarticulation of Black ontology reaffirms that Blackness is not concerned with whiteness, "in fact, I don't give a damn for him" (Fanon 1995/1952, 35), but rather with its own epistemic and ontological project, thus facilitating epistemic justice. "The immobility to which the native is 
condemned can only be called into question if the native decides to put an end to the history of colonisation - the history of pillage - and bring into existence the history of the nation" (Fanon $1995 / 1952,41)$. Bringing an end to the history of colonisation signifies an earnest commitment to self-articulation through engagements with the Black Archive, which subverts imposed epistemic framework, subsequently facilitating epistemic justice and access in the contemporary South African academe.

Resisting ontological denial is rooted in anti-colonial strategies that are not concerned with the project of whiteness and its attendant coloniality. Rather the objective becomes a concerted effort at defining Black ontology through the use of the Black Archive. My insistence on the use of the Black Archive as a mode of self-articulation is rooted in two motivations; first, an earnest engagement with the Black Archive substantially troubles the claim of epistemicide and reveals modes of collusion with coloniality in exacerbating the denial of the scholarship of Black/Indigenous intellectuals. Secondly, a concern with the Black Archive moves away from the notion of history only having begun with the colonial moment of contact (Mamdani 2001). In a discussion that considers the Rwandan genocide, Mamdani points out that in clinging to political identities that were derived from the colonial project, Africa continues to validate the colonial project; "[most] states in Africa continue to adhere to this claim, considering as 'native' only those who were present on native soil at the time of colonisation ... [the] irony is that for a postcolonial state to make this claim is to uphold the colonial state as its true parent" (Mamdani 2001, 31). My incessant concern with the Black Archive is thus aimed at redefining this history that is characterised by Blackness continuously proclaiming the epistemic positions that are framed as violent. Through clinging to these modes of definition, Blackness proclaims that its legitimacy and being are derived from the very epistemic violences it seeks to subvert. "Colonialism is not a thinking machine, nor a body endowed with reasoning faculties. It is violence in its natural state, and it will only end when confronted with greater violence" (Fanon 1995/1952, 48).

While I agree with Fanon, in that colonialism and its derivative - coloniality - are absolute violence, I suggest that the violence in the HWU that is predicated on sustained epistemic harms can yield without the use of greater violence. This claim is rooted in the possibilities that lie in an earnest engagement with the Black Archive, as developed above. The social conditions under which the contemporary HWU functions are framed as changing. This assertion finds its substantiation in the legislation that governs higher education in South Africa. Contemporary legislation aspires to see this institution emulate a Socratic conception of the University, whereby this it is responsive to its locale and attends to the social demands that are placed on it. 
To frame the University as rooted in the Socratic tradition comes from the Education White Paper 3 (Department of Education 1997), which defines the University as a social institution that is both democratic and accepting of opposing and dissenting views, and fosters the contestation of ideas. This definition continues in the tradition of South African academics who have defined the role of institutional autonomy and academic freedom as undergirding principles that are sacrosanct to institutional governance. Academic freedom and institutional autonomy have been used in the past to resist and challenge state interference and ideology that aims to meddle with the internal affairs of the university.

From this perspective, the university is not characteristically defined as a totalitarian institution that silences dissenters. Furthermore, through the use of academic freedom, Black intellectuals in the HWU can begin using the Black Archive as a mode of challenging western epistemic paradigms in these institutions. The use of the Black archive challenges notions of epistemicide in our context, while revealing that the social conditions that necessitate the suspension of the ethical, thus ushering in the use of violence as an emancipatory tool, were not present in the South African contestation that manifested as the \#MustFall movements.

\section{CONCLUSION}

Rooted in a praxis that aims to overthrow systems of oppression, injustice and coloniality/modernity - a Eurocentric modernism/modernity; decoloniality and allied strategies are aimed at resisting colonialism and coloniality in contemporary society. However, caution ought to be heeded in our decolonial strategies, for the conflation of history with contemporary society leads to unreflective and irresponsible modes of resistance that are unilateral in form and lack the intellectual tradition of reasoned thought and criticality. Obsessive in their desire to be in solidarity with the student movement, intellectuals that supported the use of democratic violence relinquished their ethical responsibility as owed to society, which resulted in what I interpret to be a dereliction of duty. Intellectuals whom irresponsibly supported the use of violence in the South Africa higher educational landscape adopted decoloniality/decolonisation only in a metaphorical sense, without substantive knowledge of its implications.

It has been my project to showcase that Blackness and its modes of resistance are not rooted in rage, anger and an insatiable desire to raze institutions to the ground. It is from this position that I maintain that the use of democratic violence in the academe was unsubstantiated as the conditions that exist(ed) do not necessitate the suspension of the ethical. My argument has showcased that there exists an alternative for Blackness through a self-articulated ontology. I would suggest that these self-articulated conceptions of ontology may lead us to realising further liberatory alternatives. The recognition of the humanity of the self and others is rooted 
in the notion of a commonly shared humanness as detailed by Ramose. Ramose (2007) distinguishes between a "humanism and a humanness", by indicating that the former describes a finitude and finality while the latter indicates a constant attempt towards a holistic vision. A humanness allows the Other, who in my instance - as a Black Queer man - can be interpreted as an oppressor, the capacity to overcome their oppressive frameworks of bigotry, racism, sexism, epistemic injustice and anti-Blackness.

What is proffered here as a response to the continued negation and epistemic violences meted out on the bodies of Blackness in these institutions is a pedagogical approach that is rooted in the Black Archive. This approach, that is rooted in the Black Archive, is cognisant of the post-conflictual nature of South African society, and aims to inculcate in the student and the pedagogue an agency that has long been denied to Blackness owing to colonial impositions that manifest as epistemic harms. Blackness and Black ontology ought to use its history of trauma, endured violences and suffering summed up by Senghor, quoted in Sartre as a mode of redefining the trajectory of the South African university.

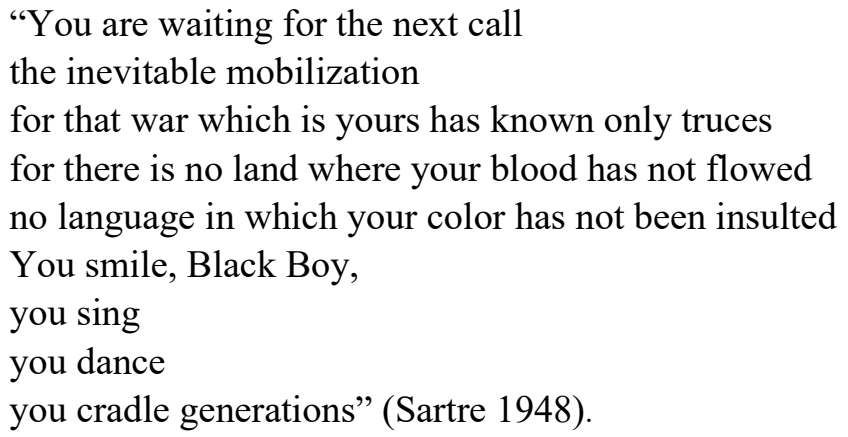

\section{ACKNOWLEDGEMENTS}

I am grateful to Lis Lange and Vasu Reddy for their comments and suggestions to an earlier version of this article, when it was still intended for University on the Border. Your critical insights and comments were very useful in sharpening my argument.

\section{NOTES}

1. I use a capitalized orthography when writing about the University, denoting my representation of the University as institution. This is to say that when I capitalize the spelling, I am referring to the system as a whole and not a single institution.

2. The concepts of authenticity and purity, should themselves not be read without the baggage that they carry, for in appealing to an authentic conception of Black ontology, society denies the reality that Blackness is constantly changing, fluid and is defined by contestations owing to the varying conceptions of this identity. In simple terms, there is no hegemonic notion of Blackness that is uncontested and neat. Put differently, I am here agreeing with Mamdani (2005) when he maintains that in certain contexts, Blackness has existed within the categories that were the invention of European modes of thinking - as per Mudimbe's (1988) contention. 
3. For a detailed analysis of the why I elect to write post-colony in this way, see Kumalo (2020a) as I follow his line of thinking when he proffers the reasons for this lexicographical representation.

4. While I acknowledge the scholarship of decolonial thinkers and their contributions on epistemic erasures and modes of silencing used in the westernised university (Grosfoguel 2013; Nyoka 2013; Lebakeng, Phalane and Nase 2006; Almeida and Kumalo 2018), I wish to briefly trouble the notion of epistemicide in the context of the South African Higher Education landscape. I acknowledge that there have been considerable efforts at silencing and erasing Indigenous epistemic positions but I cannot concede the point of epistemicide as Indigenous Knowledge Systems and epistemic frameworks continue to exist. To claim epistemicide, is to claim complete and absolute annihilation, which is not the case in our context.

5. As discussed in the work of Nyoka $(2013,3)$

6. In a discussion about native and settler political identities, Mamdani $(2005,3)$ reveals how "compradors" and "collaborators", created a lasting legacy of the colonial state on the African continent. It is these entanglements which I suggest create the illusory conception of Black ontology as a mode of being which can exist outside of the colonial moment of encounter.

7. The social group that the reader can understand as the wielders of democratic violence in the political showdown that defined this historical moment.

8. I understand the police to be a representation of legitimate violence through their association with the state.

9. Greg Nicolson, "\#FeesMustFall: Another day of violence as the state kicks issues forward". The Daily Maverick, 12 October 2015. https://www.dailymaverick.co.za/article/2016-10-12feesmustfall-another-day-of-violence-as-the-state-kicks-issues-forward/\#.Wq2AN-hubIU (Accessed 10 March 2018).

10. The students who were incarcerated were not only Black students. However, the focus on those incarcerated was primarily given to Black students owing to the fact that the \#MustFall movements were concerned with the reclamation and affirmation of Black ontologies in HWUs.

11. Sune Payne, "\#FeesMustFall: Let's have a TRC for students arrested during fees protests, say marchers to Parliament". The Daily Maverick, 4 April 2018. https://www.dailymaverick.co.za/ article/2018-04-04-feesmustfall-lets-have-a-trc-for-students-arrested-during-fees-protests-saymarchers-to-parliament/\#.WtSPrYhubIU (Accessed 6 April 2018).

12. Paddy O'Halloran, "Student politics in SA: A response to critics". The Con, 7 October 2015. http://www.theconmag.co.za/2015/10/07/student-politics-in-sa-a-response-to-critics/ (Accessed 20 June 2016).

13. Gordon (2015), reading the text in its French iteration rightly titles the work The Damned of the Earth. This comes from a closer reading of Fanon's work from the French tradition and suggests that the title ought to be reframed from the Wretched to the Damned.

14. I will once again direct my reader to Kumalo's formulation of the reasoning behind the orthographical choice in writing the concept without parentheses in this case. This is detailed in note 19 , where in a distinction is made between the two orthographical choices.

15. For a detailed analysis of this claim, see Kumalo's (2020b) objection to the way in which Leonhard Praeg (2014) has theorized ubuntu in his paper entitled Curriculating from the Black Archive Marginality as Novelty.

16. On the matter of the Black Archive as developed using European languages, in the case of English, there has and continues to be a longstanding debate around this matter with Kunene $(1992,32)$ arguing, "writers who write in a foreign language are already part of foreign institutions; to one extent or another, they have adopted foreign values and philosophical attitudes, and they variously seek to be a member of that culture." The same claim can be said of the importation of Africana philosophy and its uses in reading a context that is defined by a range of differences that are dissimilar in subtle yet poignant ways. Simply, extraversion in this form suggests a betrayal of what can be understood as the contestation of visibility that was staked by the students who were agitating for change in the sector. 


\section{REFERENCES}

Abrahams, Yvette. 2003. "Colonialism, dysfunction and disjuncture: Sarah Bartman's resistance (Remix)." Agenda: Empowering women for Gender Equity 17(58): 12-26.

Almeida, Shana, and Siseko H. Kumalo. 2018. "(De)coloniality through indigeneity - Deconstructing calls to decolonise in the South African and Canadian university contexts." Education as Change 22(1): 1-24.

Angu, Pineteh E., Naomi Boakye, and Oscar O. Eybers. 2020. "Rethinking the teaching of academic literacy in the context of call for curriculum decolonisation in South Africa." The International Journal of Pedagogy and Curriculum 27(1): 1-17.

Bangeni, Bongi, and Rochelle Kapp. 2007. "Shifting language attitudes in linguistically diverse learning environment in South Africa." Journal of Multilingual and Multicultural Development 28(4): 253-269.

Biko, Steve B. 2004/1978. I write what I like. Johannesburg: Picador Africa.

Boughey, Chrissie. 2002. “'Naming' students' problems: An analysis of language related discourses at a South African university." Teaching in Higher Education 7(3): 295-307.

Boughey, Chrissie, and Sioux McKenna. 2016. "Academic literacy and the decontextualised learner." Critical Studies in Teaching and Learning 4(2): 1-9.

Department of Education. 1997. Education White Paper 3: A programme for the transformation of Higher Education. Pretoria: Ministry of Education.

Dixon, John, and Kevin Durrheim. 2000. "Displacing place-identity: A discursive approach to locating self and other." British Journal of Social Psychology 39: 27-44.

Dussel, Enrique. 1985. Philosophy of liberation. New York: Orbis Books.

Fanon, Fanon. 1995/1952. The fact of Blackness. In The post-colonial studies reader, ed. Bill Ashcroft, Gareth Griffiths and Helen Tiffin. $2^{\text {nd }}$ Edition. London and New York: Routledge Publishers.

Gordan, Lewis R. 2015. What Fanon said: A philosophical introduction to his life and thought. New York: Fordham University Press.

Grosfoguel, Ramon. 2013. "The structure of knowledge in Westernised universities: Epistemic racism/sexism and the four genocides/epistemicides of the long $16^{\text {th }}$ Century." Human Architecture: Journal of Sociology of Self-Knowledge 11(1): 73-90.

Honderich, Ted. 1980. Violence for equality: Inquiries in political philosophy. Harmondsworth: Penguin Publisher Ltd.

Ikuenobe, Polycarp. 2006. Philosophical perspectives on communalism and morality in African traditions. Lexington Books.

Kumalo, Siseko H. 2021. Decolonisation as democratisation: Global insights into the South African experience. Cape Town: HSRC Press.

Kumalo, Siseko H. 2020a. "Resurrecting the Black Archive through the decolonisation of philosophy in South Africa." Third World Thematics 5(1-2): 19-32.

Kumalo, Siseko H. 2020b. "Curriculating from the Black Archive - Marginality as novelty." Critical Studies in Teaching and Learning 8(1): 111-132.

Kunene, Mazisi. 1992. "Problems in African literature." Research in African Literatures 23(1): 27-44.

Lebakeng, Teboho, J., Manthiba M. Phalane, and Dalindjebo Nase. 2006. "Epistemicide, institutional cultures and imperative for the Africanisation of universities in South Africa." Alternation 13(1): 70-87.

Mamdani, Mahmood. 2001. When victims become killers: Colonialism, nativism and the genocide in Rwanda. Princeton: Princeton University Press.

Mamdani, Mahmood. 2005. Political identity, citizenship and ethnicity in post-colonial Africa. A 
keynote address in Arusha conference. New frontiers of social policy - December 2005: 12-15.

Maitra, Ishani. 2010. "The nature of epistemic injustice." Philosophical Books 51(4): 195-211.

Mbembe, Achille. 2015. "The State of South African Political Life". Africa is a Country, 19 September 2015. https://africasacountry.com/2015/09/achille-mbembe-on-the-state-of-south-african-politics (Accessed 20 June 2016).

Morreira, Shannon, and Mayu Hayakawa. 2015. "Introduction: Knowledge production in a time of 'crisis'." Social Dynamics: A Journal of African Studies 41(2): 215-218.

Mthembu, R. H. 1985. UMamazane. Pietermaritzburg: TW Griggs and Co.

Mqhayi, Samuel E. K. 1914. Ityala Lamawele. Lovedale: Lovedale Press.

Mudimbe, Velantin-Yves. 1988. The invention of Africa: Gnosis, philosophy and the order of knowledge. Bloomington: Indiana Univeristy Press.

Nakata, Martin, Victoria Nakata, Sarah Keech, and Rueben Bolt. 2012. "Decolonial goals and pedagogies for Indigenous studies." Decolonization: Indigeneity, Education \& Society 1(1): 120 140.

Nkosi, Lewis. 1989. "Review: White writing.” Third World Quarterly 11(1):157-161.

Nyembezi, Sibusiso C. L. 1958. Lafa Elihle Kakhulu. Pietermaritzburg: Shutter and Shooter Publishers.

Nyoka, Bongani. 2013. "Negation and affirmation: A critique of sociology in South Africa." African Sociological Review/Revue Africaine de Sociologie 17(1): 2-24.

Praeg, Leonhard. 2014. A Report on Ubuntu. Scottsville: UKZN Press.

Ramose, Mogobe B. 2007. "But Hans Kelsen was not born in Africa: A reply to Thaddeus Metz." South African Journal of Philosophy 26(4): 347-355.

Ramose, Mogobe B. 2016. Modu Wa Taba. Unpublished paper - presented at Rhodes University Transformation Summit.

Sartre, Jean-Paul. 1948. "Black Orpheus.” The Massachusetts Review 6(1): 13-52.

Soga, Tiyo B. 1898. Intlalo kaXhosa. Lovedale: Lovedale Press.

Wicomb, Zoe. 2018/1995. "Reading, writing, and visual production in the new South Africa." In Race, nation, translation: South African essays, 1990-2013, ed. A van der Vlies, 66-80. Johannesburg: Wits University Press. 